\title{
Transition of blind women to motherhood from the perspective of Transitions Theory
}

\author{
Transição de mulheres cegas para a maternidade na perspectiva da Teoria das Transições
}

Transición de mujeres ciegas para la maternidad en la perspectiva de la Teoría de las Transiciones

'Universidade do Estado do Rio de Janeiro. Rio de Janeiro, Rio de Janeiro, Brazil.

"Universidade Estadual do Sudoeste da Bahia. Jequié,

Bahia, Brazil.

How to cite this article:

Santos RS, Ribeiro VM. Transition of blind women to motherhood from the perspective of Transitions Theory. Rev Bras Enferm. 2020;73(Suppl 4):e20190234.

doi: http://dx.doi.org/10.1590/0034-7167-2019-0234

\section{Corresponding author:}

Vivian Mara Ribeiro

E-mail:vmribeiro@uesb.edu.br

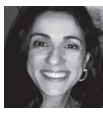

EDITOR IN CHIEF: Antonio José de Almeida Filho ASSOCIATE EDITOR: Fátima Helena Espírito Santo

Submission: 03-15-2019

Approval: 03-23-2020

\section{ABSTRACT}

Objective: to analyze the transition of blind women to motherhood from the perspective of Transitions Theory. Method: a qualitative, descriptive study, which had as participants 11 blind women. An open interview was conducted using the narrative method. Analysis occurred in the light of Transitions Theory, with approval from the Research Ethics Committee with Human Beings. Results: the age group was 32 to 63 years, mostly Catholic, with social security benefits. Transition to motherhood mainly evidenced the experience when becoming a mother and feelings related to this new phase of life. Final considerations: the women in the study adapted themselves to the maternal role, even with difficulties, developed healthy relationships with their children, overcame their disability and nurtured dreams and desires. They were aware of their role, achieving with mastery a healthy transition. It was evidenced scarcity of nursing therapies.

Descriptors: Visually Impaired Person; Maternal and Child Health; Nursing; Nursing Care; Nursing Theory.

\section{RESUMO}

Objetivo: analisar a transição de mulheres cegas para a maternidade na perspectiva da Teoria das Transições. Método: pesquisa qualitativa, descritiva, que teve como participantes 11 mulheres cegas. Realizou-se entrevista aberta por meio do método de Narrativa de Vida, e a análise ocorreu à luz da Teoria das Transições, com aprovação do Comitê de Ética em Pesquisa com Seres Humanos. Resultados: a faixa etária foi de 32 a 63 anos, a maioria era católica e com benefícios da seguridade social. A transição da maternidade evidenciou principalmente a experiência vivenciada ao se tornar mãe e sentimentos relacionados a essa nova fase da vida. Considerações finais: as mulheres participantes do estudo se adaptaram ao papel materno, mesmo com as dificuldades, desenvolveram relações saudáveis com os filhos, superaram a deficiência e cultivaram sonhos e desejos, conscientes de seu papel, alcançando a maestria da transição saudável. Evidenciou-se a escassez das terapêuticas de enfermagem.

Descritores: Pessoas com Deficiência Visual; Saúde Materno-Infantil; Enfermagem; Cuidado de Enfermagem; Teoria de Enfermagem.

\section{RESUMEN}

Objetivo: analizar la transición de mujeres ciegas para la maternidad en la perspectiva de la Teoría de las Transiciones. Método: investigación cualitativa, descriptiva, con 11 mujeres ciegas participando. Se realizó una entrevista abierta utilizando el método Narrativa de la vida y el análisis se realizó a la luz de la Teoría de la transición, con la aprobación del Comité de ética en investigación con seres humanos. Resultados: el grupo de edad tenía entre 32 y 63 años, la mayoría católicos con beneficios de seguridad social. La transición de la maternidad mostró principalmente la experiencia de convertirse en madre y los sentimientos relacionados con esta nueva fase de la vida. Consideraciones finales: las mujeres que participaron en el estudio se adaptaron al papel materno, a pesar de las dificultades, desarrollaron relaciones saludables con sus hijos, superaron la discapacidad y cultivaron sueños y deseos, conscientes de su papel, logrando el dominio de la transición saludable. Había escasez de terapias de enfermería. Descriptores: Personas con Daño Visual; Salud Materno-Infantil; Enfermería; Cuidado de Enfermería; Teoría de Enfermería. 


\section{INTRODUCTION}

This study had as its object the transition to motherhood for blind women from the perspective of Afaf Meleis'Transitions Theory. Transiting to motherhood is a period of adaptation of life and requires health monitoring for all women who want or are going through this change, because it is a time of preparation for the exercise of motherhood $^{(1)}$. Care for women in the process of motherhood and their family should be performed by health professionals before, during and after pregnancy. Nurses play an important role because they occupy many of these health care spaces, whether in the family planning service, prenatal care, during childbirth or postpartum or in monitoring the growth and development of the child. Every person should have access to this follow-up, health services and health professionals prepared for comprehensive and universal care, in the different periods of transition of life. That includes people with disabilities, whatever this disability is. They must have recognized specificities and receive health actions focused on their needs, for the same comprehensive and individualized care ${ }^{(2-3)}$. When they are blind women, who wish or are in transition to motherhood, health services gradually occupy spaces, but are not yet perceived in their singularity. Since they are a smaller proportion of the female population, they face situations of invisibility, although it is stated that the number of blind women of all ages has increased ${ }^{(4)}$.

The transitions experienced by a person can be classified according to the Transitions Theory by their nature, types, patterns and properties. They are classified as developmental transitions if they occur in the individual's life cycle. If they are related to the change of roles in society, they are called situational transitions; health-disease, if related to changes in personal and family wellbeing; and organizational, if they are related to changes in the social, political and economic context ${ }^{(5-6)}$.

In the transition to motherhood, in addition to the woman's emotional state, her needs and personal history must be considered, so that she can gain confidence in herself and her abilities as a mother. Nursing could act to understand the transition from the perspective of those who experience it, and identify care needs $s^{(5,7)}$. In addition to assisting blind women with regard to their sexuality and desire to either experience motherhood or not, the whole transition process should be encouraged - their autonomy as women and mothers, and the relationship between them and their child. When analyzing studies with blind mothers, it was observed that communication was focused among the majority. Interaction between blind mothers and their children direct to the daily care of children, and few directly address the perspective of mothers ${ }^{(8-15)}$. Therefore, a gap to be researched is identified.

\section{OBJECTIVE}

To analyze the transition of blind women to motherhood from the perspective of Afaf Meleis'Transitions Theory.

\section{METHOD}

\section{Ethical aspects}

The project was submitted and approved by the Research Ethics Committee with Human Beings of the Health Multidisciplinary
Institute at the Universidade Federal da Bahia. Data collection began only after authorization from the institution and a favorable opinion from the REC, verbal consent and signature of the terms by participants. Terms were made in printed version, Braille version and expanded source version. Anonymity and privacy were guaranteed to the informants, considering the ethical aspects that involve research with human beings ${ }^{(16-17)}$. To preserve participant anonymity, the acronym "In" was assigned to "Interviewee" and the corresponding number of each interview for identification, although several participants expressed that their own name could be used and the interview could be identified.

\section{Theoretical-methodological framework}

By understanding the transition to motherhood as a delicate moment in a woman's life, and in view of the need to know and discuss how it occurs, it was proposed to use the Transitions Theory to support the study. It is a medium-range theory that has as theme the individual and family life cycle and the changes that occur there ${ }^{(1)}$. The Transitions Theory proposes the nature of the transition, the conditions in which the transition occurs and the individual's response patterns to be considered. Its theoretical structure consists of types and patterns of transitions, properties of transition experiences, transition conditions, facilitators and inhibitors, process indicators, outcome indicators, and nursing therapies ${ }^{(1)}$.

\section{Type of study}

This is a study with a qualitative, descriptive approach, characterized by an ethnossociological perspective. The characteristic of ethnossociological research is to concentrate its studies in a particular social world or specific activity related to a group of people who are in the same social situation ${ }^{(18)}$.

\section{Methodological procedures}

Information was collected through an open-ended interview, using the narrative method ${ }^{(18)}$. Participants were invited by the researcher to share the experiences through a specific theme, and they were informed about the researcher's knowledge interests (filter) from the first contact. The interview began from a general guidance on the object of study. Filters were applied that specifically targeted the questions or doubts that arose by the interviewer. Interview narratives are open and dialogical, and develop only when the participant begins to appropriate the conduct of the interview. In other words, the participant conducts the interview and decides what and when she will talk about a certain subject ${ }^{(18)}$.

In the narrative method, it is not necessary for the participant to be experiencing the situation addressed during the interview. She can be interviewed at any time in her life, because she will summarize her experience and will report the feelings, emotions and narratives inherent to the moment in which she experienced the investigated situation $^{(19)}$. A script was used for sociodemographic characterization. The interview had a single question presented by the researcher, who directed the participant's narrative: what change did you notice in you and in your life after the birth of your child? Filters were used to extract information that needed to be clarified ${ }^{(18)}$, asking women to answer the initial question focusing on the change from woman 
to mother; how they felt living this change; how they felt during pregnancy; how they felt after the birth of their child; if she wanted to be a mother; and what facilities and difficulties were experienced when becoming a mother or to care for the child.

\section{Study setting and data source}

The study was developed in a Blind People's Association (AJECE - Associação Jequieense de (egos) based in the countryside of the state of Bahia, between April and September 2017. The city of Blind People's Association, founded in 1994, carries out activities with the aim of including and prevailing the rights of people with visual impairment. Currently with the title of non-governmental institution, the association serves about 100 associates of the host city and surrounding cities and develops internal and external activities ${ }^{(20)}$. Participant selection adopted as inclusion criteria: women already blinded when experiencing motherhood, and as exclusion criteria: blind women who presented some space/time disorientation that prevented them from granting the interview. There was no refusal of any participant, and 11 interviews were conducted.

\section{Data collection and organization}

The interviews occurred only once with each participant, uneventfully, in the association, in the pedagogical follow-up and early encouragement rooms, with a minimum duration of 09 minutes and 40 seconds, a and maximum of 01 hour and 17 minutes. In possession of a field diary, all the signs and facial expressions of the participants were observed and recorded by the researcher. There were moments of emotion, crying and laughter. They expressed as if they also reflected on their own lives, rethought what they lived and how they reacted to certain situations. The interviews followed in a welcoming environment; interferences happened only at times when it was essential to summarize some sentence spoken by the participants to extract more elements on the theme of the research. The criterion of recidivism of information was applied to reach a limit of interviews and as the themes or arguments were repeated, information saturation ${ }^{(18,21)}$ was characterized.

\section{Analysis of narratives}

Narrative analysis began with the first three interviews, the beacons, which developed parallel to the collection of other narratives. From the interviews, meanings pertinent to the research object emerged, which became indications for the formulation of hypothesis at the end of the investigation ${ }^{(18)}$. Thematic, comparative analysis of facts and occurrences that would have in common their temporal order was performed, indicating the diachronic structure of the lived experiences ${ }^{(18)}$. With the exhaustive reading of the interviews, there was the codification and recoding of the themes that served to aggregate the recurring themes among the narratives and notice what appeared most similar among them, identifying themes more addressed and less addressed. All interviews were analyzed one by one attentively and exhaustively. Perhaps other themes are highlighted in the perspectives of different researchers, because the life history of researchers and their experiences influence the way they analyze the narrative of other people's lives ${ }^{(18)}$.

\section{RESULTS}

Eleven blind women aged 32 to 63 years participated in the research; the predominant religion was Catholic; family income was around social security benefits (sickness benefit and others), retirement by age or disability and family pension; and only two women maintained performing paid activities. Most reported that they studied until the $6^{\text {th }}$ grade of Elementary School II, and only two completed Higher Education. Some women take Braille classes in the association, with teaching compatible with the degree of education. Only two come from cities surrounding the research municipality, most live with family members, and one lives alone and reported that she does so by choice, because she likes to have her space. Concerning activities performed, one of the women reported that she attends pedagogy school, another

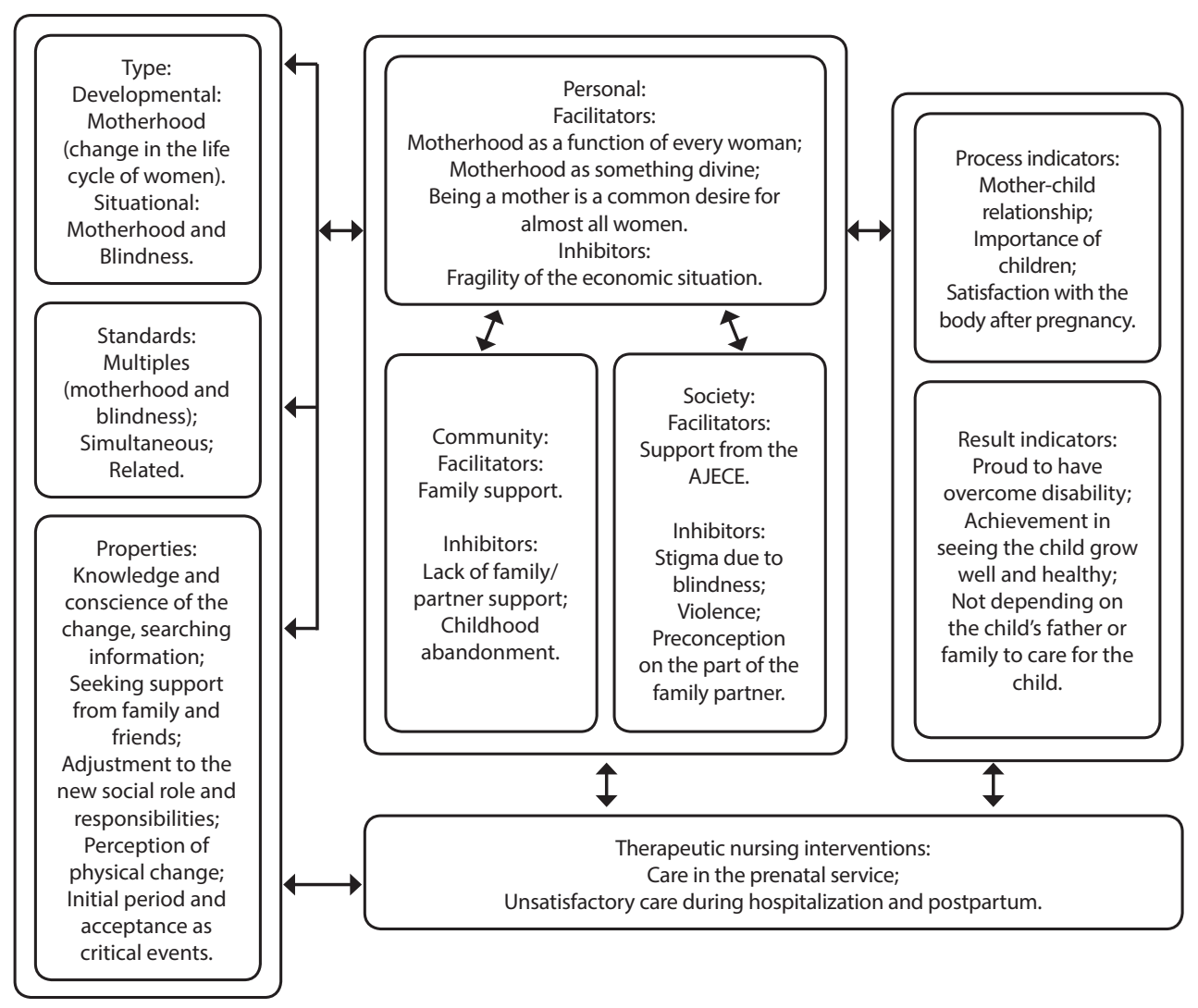

Figure 1 - Transition of blind women to motherhood according to Meleis'Transitions Theory 
develops works as an actress, singer and composer, and two others are teachers at the Blind People's Association. All other women reported taking care of the house and activities in the association. Activities range from Braille, cursive writing, ALA (autonomous life activities), computing and stretching, sport, Soroban (Japanese abacus to do mathematical calculations) and participation in the prayer group. Experiencing motherhood was also addressed and revealed that most women had natural birth. The number of children varied between one and four children, with current age between six and 34 years. Breastfeeding occurred among most mothers, with an average duration of approximately 18 months.

Figure 1 describes how the transition to motherhood occurred in the context of blind women participating in the study, following the elements proposed by Transitions Theory ${ }^{(1)}$.

Motherhood transition addressed mainly the experience of becoming a mother, from the changes that occurred to her adaptations and feelings related to this new phase of life; facilities and difficulties in the context of motherhood, such as the support they received during and after pregnancy, contrasting with situations of prejudice and insecurity experienced and the scarce nursing care in the transition to motherhood demonstrated by situations in which nursing could effectively collaborate in the motherhood process of these women.

\section{DISCUSSION}

Among the study participants, it was observed that only a small number of women report that they perform paid work, showing little insertion in the labor market, which may also be related to the level of education and access to education, since most of the interviewees attended only Elementary School.

By identifying how the transition occurred, it is possible to define exactly when nursing can intervene in the care of blind women in transition to motherhood, knowing the process and care, in addition to the difficulties encountered. In this context, the category, "Motherhood of Blind Women from the Perspective of Afaf Meleis", identified that the narratives of blind women showed developmental and situational transitions.

Transition type and pattern: Body changes, hormonal changes and adaptation of the woman's body to receive another being occur with women who can biologically develop a pregnancy. Thus, it is understood as developmental transition, as it occurs in the woman's life cycle and leads to bodily maturation.

Upon becoming a mother, the woman changes her role in society, adding other activities, responsibilities and needs that she did not have before, which would lead motherhood to be understood as situational transition.

During the entire process of motherhood, women undergo changes, from the decision to become pregnant or continue the pregnancy, the preparation for pregnancy, the changes that occur in their body, the way this pregnancy is received until the adaptation to the new situation to be a mother and take care of their children.

The process in which women prepare to be mothers, understand the reality, adapt themselves to their babies, dream and plan a good life for themselves and their children and family goes from the decision to become pregnant until the moment when the maternal care is incorporated into her identity ${ }^{(1)}$.
Adapting to the new role and incorporating maternal care into their identity can take less or longer for women and depends a lot on the context in which they live, how and with whom they live and a support network is available. Therefore, positive and negative experiences are seen in the motherhood process, and this engagement can be varied for each woman.

Motherhood of blind women is a transition process of multiple, sequential, simultaneous pattern, and relates, in most cases, motherhood and blindness.

With regard to the women participating in the study, it is evident that they experienced the transition to motherhood, and the transition from being blind during the period of pregnancy or immediately before, which makes them have experienced two concomitant transitions.

By becoming blind, women change roles in the family, for instance. They cease to be providers, or caregivers, at least for a while, until they accept themselves blind and relearn activities. In addition to the whole process that follows from the discovery of what caused blindness, treatment (in some cases), personal and family acceptance are ways of adapting to their lives, until they learn how to live under the new condition, which characterizes situational transition.

As for the transition properties, the transition experiences have properties that address how the individual positions himself in the face of change, and are essential elements for understanding the transition, such as knowledge/awareness; adjustment/commitment; change and difference; critical events and happenings; experience period. The properties are not necessarily distinct, they are interrelated $\mathrm{d}^{(1,5-6)}$.

Through narratives, it was observed that blind women developed knowledge and awareness of the change that motherhood caused, sought information and support from family members and friends and, in some cases, although few, from health professionals.

The adjustment to the new social role and the commitment to the new responsibilities that motherhood brought were observed, and in addition, the adjustment to his personal condition of blindness, to the change in lifestyle, to the adaptation to the child's needs, as evidenced in the following narrative.

When he was born, I had to breastfeed for a year and five months, it was when I really realized my responsibility to be a mother. Look, I got pregnant when I was young, I just wanted to go out, dressed up, go to the salon, commitment was only with me. (In 07)

Stop thinking only of themselves to dedicate to their child and adapting themselves to a new lifestyle are important transformations that occur in the life of all women when they become a mother, so there must be a support network that supports and understands them and that it allows greater lightness in life changes and that it adapts well to the role.

Women narrated that they noticed the difference in their body, and highlight the feeling of feeling autonomous and independent.

[...] I changed, I was a person, I was not like that before, I did not feel independent, but after becoming a mother, I was an independent person, taking care of the child and my life [...]. (In 04)

First, that way... there is a transformation in our body, in our mind, in our psychological... and there is also the issue that we get very 
fat, sometimes we cannot lose weight anymore, and have all that difficulty [...]. (In 06)

The participants showed adjustment to body and attitude changes, for some women this change can be beneficial and for others it is not, since in our society a standard of beauty and female behavior is valued that does not always apply to all women, causing frustration.

The discovery of pregnancy and the acceptance of visual impairment were described as critical events, marked by insecurities and concerns about what life would be like from that moment on. During the interviews, many women recalled and were moved to remember the fears and insecurities they felt when they became blind and some in the concomitant process of being blind and discovering pregnancy.

That's how it was, until then I didn't imagine having another child after I lost my vision [...] and the moment came, right, when I got pregnant. It was scary... the feeling was only one of rejection at first. It was my acceptance, right? It was two moments, my acceptance as disabled and the rejection of having another child, right? So, it was that acceptance thing. (In 11)

In the context of In 11, the loss of vision came concurrently with the surprise of her third pregnancy, which made her very hesitant. However, in her narrative she made clear the support she received from an AJECE social worker during this discovery process until acceptance.

They stressed the time they had to learn to be a mother. The term "learn" appeared naturally in the narratives, naturalized probably by the fact that they always have to learn or relearn things in life and adapt to blindness, new environments, walking alone, crossing the street and other activities considered routine.

Everything I can learn, even as long as God allows me to see, I will learn so I can enjoy it later. So, that's why I worry so much about the organization today, I worry a lot, I'm very sloppy about the organization at home, right? For us to have no difficulty doing things. (In 10)

Demonstrating that they want to learn to be a mother and adapt themselves to the condition of blindness and understanding these as critical events are also a demonstration of strength and courage in the face of life confrontations.

With regard to the conditions of the transition, there are conditions that can be facilitating or inhibiting and influence those who are going through the transition process. They are related to personal conditions (meanings, beliefs, cultural attitudes, socioeconomic level, preparation, and knowledge), community conditions in which the individual is inserted (support, information, advice, models) and social conditions (marginalization, stigmas, and socially defined roles) $)^{(5-6)}$.

In the context of blind women, the narratives bring as facilitating questions those related to the meaning and beliefs of motherhood as an understanding that the role of all women is to be a mother, the belief in motherhood as something divine, and the cultural attitude that defines that being mother is a desire common to all women. What could inhibit other women by not agreeing with the above premises, in the case of blind women, encouraged them, reinforced, by the idea that because they were women, they would be able and able to be a mother.

\begin{abstract}
Motherhood for me is a very special thing [...]. So, it was a very special thing in my life. I lived like this, very alone [...] like this [...] when I had my son it was a pleasure, right? (In 01)

Because a disabled person as a mother is a great joy for God to do, to give me this opportunity. I feel very happy. (In 04)

I am fine, until today, thank God. God gave me the children, right, that for me was a blessing, and it's being. (In 09)
\end{abstract}

The dubious feelings that they experienced about the loss of vision influenced them as inhibitors in the transition to motherhood. If for some women the condition of being blind was faced with attitudes of strength and courage, some interviewees narrated the non-acceptance of blindness and the loss of independence, making the adaptation process more painful.

[...] and then I went to work in the kitchens, domestic, I went to work picking up coffee, already with a disability problem, because I already told my family that I had a disability problem, but they did not believe. (In 02)

The socioeconomic level was observed as an inhibitor in the narratives, and shows, in evidence, the fragility of the economic situation of blind women, who mostly live on pensions or pensions. Only two women work and receive wages according to professional training. It should be noted that they did not portray the socioeconomic level as a "problem".

About the preparation and knowledge of motherhood, several reported difficulties in the first pregnancies, but with practice they managed to overcome the later problems, also in other pregnancies. They narrated about the initial insecurity of the child being born with some "vision problem", not knowing how to take care of the child, the fear of bathing and breastfeeding.

Because l, at that time, was 29 years old, I had never taken a new child in my arms. So, I was like this: Oh my God, how am I going to get home, I'm going to bathe because of the navel and all that stuff. (In 01)

I had a hard time taking care of him there, because I was scared, right? (In 08)

The fear of not knowing how to care, of not being able to breastfeed and of not being good enough was observed in the narratives, and is frequent in the motherhood process for any woman, even when there is a professional training in health. This initial insecurity is present, especially among mothers in her first pregnancy ${ }^{(22)}$. In some cases, the community condition of living with the family was facilitated by the support received, while in other narratives it was noticed that the lack of family support was an inhibiting condition and made it difficult to start adapting themselves to motherhood.

[...] I returned to my mother's house, I spoke to my mother and my mother accepted me, my father did not accept me [...] even 
so, that he was a good father too, right, but because he didn't want, he didn't accept, you know, a daughter without a husband, right [...]. (In 02)

[...] it looked like pregnancy, I took the test, I went to give it to him, and he wanted me to abort the boy. (In 04)

Participants In 02 and In 04 narrated these episodes of their lives with a very sad countenance, with heavy facial expressions and apparently very hurt by the reaction that the child's father and his family had when receiving the news of the pregnancy. However, they soon demonstrated that they managed to overcome these moments with the arrival of their children.

However, some women reported that they received some support during pregnancy and child rearing, mostly from the family, from the mother or sister, and from the partner. The greatest institutional and professional support came from AJECE ${ }^{(20)}$.

It was difficult, but my family is always together, right, I have a sister who helps me a lot, who was like this [...] at all times with me [...] yeah, S., she left to work, my daughter, to be able to help me and accompany me in the spaces, because there were two, right [...] love was such that she abandoned everything and even today she helps me with these boys, so much that people think that my children are hers, not mine. (In 09)

In which I looked for AJECE and that I had all the support, right? Of acceptance as loss of vision, like being a mother, and so, the transformation in my body was like [...] developing that fetus, I was feeling that there was a person inside who needed me a lot, and yes, that I really needed that person. So, that's what made me face everything, right? (In 11)

Even women who received institutional and family support, as observed in the narratives of participants In 09 and In 11, experienced several other difficulties such as fear of having the baby changed in the maternal ward.

I was afraid all the time, you know, of stealing my son [...] when there was no one in the family and who put my son next to me in the nursery, I kept holding in my hand, I didn't let go hand [...]. The other mothers always came to help me, and I didn't want any help, for me, at all times, they would take my son, change my son. I pat my hand all the time on my face, on my hair, on my little hand, I wanted to see some reference that I could, right? If someone else took it I would say, "No, not this one! It's mine!" (In 11)

The moment when In 11 narrated this fear was a form of confession, speaking softly and very emotionally. This fear would be a feeling experienced by women in general although not fully conscious, however, being blind makes the mothers of the study more vulnerable. Moreover, situations of family violence, such as rape, physical or verbal aggression, abandonment in childhood, abortion or family loss were evidenced in narratives, and contributed as inhibitors in the process.

Social conditions were observed in the narratives, in situations of marginalization described by women and of stigmatization due to the fact that they are blind and want to be mothers. They narrated prejudices suffered by the family, which discredited their ability to take care of the child, narrated the abandonment of their partners when they found out about the pregnancy, because they thought they would not be able to take care, and prejudice of themselves, because many times during this journey they doubted ability to care.

As for the response patterns, the process indicators and results of the transition, translate the way the individual goes through the transition and responds to changes, which can be positive, negative or neutral ${ }^{(23)}$.

At the end of the transition, it is observed whether the individual feels connected, interacts, if she is located within the transition, if she has developed confidence in herself, if she has mastered the new skills, identities or roles ${ }^{(1)}$.

Some women perceive the child as the person who will care for them in the future. Aspects of the mother-child relationship were observed in all narratives. Process indicators were identified, such as the positive relationship they developed with their children, the way they exalt the care they receive from them and the importance of them in their life.

Thanks to God these children of mine, I did not separate, and as I did not separate I have my daughter today, she takes good care of me, thanks to God, right, and I also take care of her also, her children, her daughter too. (In 03)

And today these boys help me a lot. God sent two boys to help me. A boy, right, because I like boys more [laughs], not that I have discrimination with girls, but I think they give a harder time. (In 09)

When narrating about their relationship with their children, they expressed happiness through a smile and even laughter. A sense of pride about what children became is noticeable in their narratives.

As result indicators, it is perceived the pride that blind women have to overcome the disability, demonstrate strength and ability to become a mother. The pleasure they feel when they see their child grow up healthy, and the importance of being independent of the child's father or family to take care of their child ${ }^{(1,24-27)}$. Mastery occurs at the end of a transition, when the patient already experiences a new feeling of stability. At the conclusion of the transition, the degree of mastery indicates the extent to which he achieved a healthy result of the transition ${ }^{(1,24-26)}$.

There were women who portrayed how they helped other women from their own experiences of motherhood, in addition to expressing the dream of studying and having a profession, which would be understood as achieving stability.

So, me too, after that I was also helped, I went to the hospital too, I stayed there helping many mothers too, you know, asking for help... my vocation is to be a nurse, there, to stay in the room. (In 01)

So, it's [...] my dream [...] I had a dream, I had no, I still have that dream, it is to study and be still or a psychologist, my dream was to be a police, but as at that time there was no police business, you know, that's okay. But then, there were two options - either a psychologist or a lawyer. I want to go back to school to see if I go to college, to see if I can be someone in life, I mean someone lam, right? (In 02) 
Women achieved mastery of the healthy transition to motherhood, were resilient in the face of situations imposed by life, able to deal with problems encountered, adapt to changes, overcome obstacles and ultimately react positively.

Therapeutic nursing interventions were scarce and only five narratives brought references to healthcare professionals' care, and of these, nursing was seen only in the prenatal and immediate postpartum periods.

I did prenatal care, I went to the clinic and I did prenatal care, all the tests I had to do, I took all the vaccines that I had to take. (In 04)

When observing the narratives of blind women in the process of transition to motherhood, possible nursing actions that could have been implemented are defined. They are based on their needs, taking into account difficulties or inhibiting conditions in the process ${ }^{(28)}$.

\section{Study limitations}

It is pointed out as a limitation of the study not having interviewed health professionals, especially nursing, to carry out data triangulation and enrich the analysis.

\section{Contributions to the area of nursing, health, and public policies}

Nursing's contribution to transitional care is relevant for blind women who wish to be mothers. From narratives, it is identified when nursing should act and how it would meet their needs, considering how the motherhood process of blind women occurs and how transitional care would be offered by health professionals.

\section{FINAL CONSIDERATIONS}

It is concluded that the women participating in the study adapted themselves to the maternal role, despite all the difficulties encountered and the impact caused. Despite the condition of blindness, they mothered, developed healthy relationships with their children, overcame their disability and cultivated dreams and desires, aware of their role. It is clear, from the narratives, the need to receive guidance and support for planning the pregnancy. They should prepare and get pregnant when and if they wish, and not be surprised by unwanted pregnancies. Inadequate monitoring has the same effect as the lack of monitoring by a health professional and becomes an inhibitor of the transition process, so the health professional must be prepared to meet the specifics. It is important to include in the curriculum of undergraduate nursing courses the care directed to blind women and other disabilities. It is essential to develop health education actions, guidelines, information in the prenatal care about the changes that will occur in the gestational period, nursing care in childbirth and postpartum directed to the specificities of blind women, in addition to nursing guidance on initial care of the child. baby, such as bathing, breastfeeding and accident prevention. All of this is present in the participants' narratives, of great relevance for the process to occur in the best possible way.

\section{REFERENCES}

1. Meleis Al, Sawyer LM, IM E, Messias DKH, Schumacher K. Experiencing transitions: an emerging middle range theory. In: Meleis, Al. Transitions theory: middle-range and situation-specific theories in nursing research and practice. Springer Publishing Company, LLC. 2010. 641p.

2. Ministério da Saúde (BR). Secretaria de Atenção à Saúde. Departamento de Atenção Básica. Saúde sexual e saúde reprodutiva. Editora do Ministério da Saúde, Brasília, 2010.

3. Senado Federal (BR). Estatuto da pessoa com deficiência. Senado Federal. Coordenação de Edições Técnicas. Brasília. 2015.

4. Organização Mundial de Saúde. Mulheres e saúde: evidências de hoje, agenda de amanhã. Relatório. 2011.

5. Santos E, Marcelino L, Abrantes L, Marques, C, Correia R, Coutinho E, et al. O cuidado humano transicional como foco da enfermagem: contributos das competências especializadas e linguagem classificada CIPE ${ }^{\oplus}$. Millenium [Internet]. 2015[cited 2018 Dec 02];49:153-71. Available from: http://revistas.rcaap.pt/millenium/article/view/8083

6. Shumacher KL, Meleis Al. Transitions: a central concept in nursing. In: Meleis Al. Transitions theory: middle-range and situation-specific theories in nursing research and practice. Springer Publishing Company, LLC. 2010.

7. Dias SA, Silva TQ, Venâncio DO, Chaves AFL, Lima ACMACC, Oliveira MG. Breastfeeding self-efficacy among blind mothers. Rev Bras Enferm. 2018;71(6):2969-73. doi: 10.1590/0034-7167-2017-0942

8. Oliveira PMP, Rebouças CBA, Pagliuca LMF. Construção de uma tecnologia assistiva para validação entre cegos: enfoque na amamentação. Rev Bras Enferm. 2009;62(6):837-43. doi: 10.1590/\$0034-71672009000600006

9. Wanderley LD, Barbosa GOL, Pagliuca LMF, Oliveira PMP, Almeida PC, Rebouças CBA. Comunicação verbal e não-verbal de mãe cega durante a higiene corporal da criança. Rev RENE. 2010;11(N-Esp):150-9. Available from: http://www.periodicos.ufc.br/rene/article/view/4697/3494

10. Pagliuca LMF, Barbosa GOL, Wanderley LD, Oliveira PMP. Análise da comunicação verbal e não verbal de uma mãe cega e com limitação motora durante a amamentação. Rev Bras Enferm. 2011;64(3):431-7. doi: 10.1590/S0034-71672011000300004

11. Barbosa GOL, Wanderley LD, Oliveira PMP, Rebouças CBA, Almeida PC, Pagliuca LMF. Comunicação verbal e não verbal de mãe cega e com limitação motora durante alimentação da criança. Acta Paul Enferm. 2011;24(5):663-69. doi: 10.1590/S0103-21002011000500011

12. Senju A, Tucker L, Pasco G, Hudry K, Elsabbagh M, Charman T, Johnson MH. The importance of the eyes: communication skills in infants of blind parents. Proc R Soc B. 2013;280. doi: 10.1098/rspb.2013.0436 
13. Jorge HMF, Bezerra JF, Oriá MOB, Brasil CCP, Araujo MAL, Silva RM. Enfrentamento de mães cegas no acompanhamento dos filhos menores de 12 anos. Texto Contexto Enferm. 2014;23(4):1013-21. doi: 10.1590/0104-07072014002920012

14. Chiesa S, Galati D, Schmidt S. Communicative interactions between visually impaired mothers and their sighted children: analysis of gaze, facial expressions, voice and physical contacts. Child: Care, Health Develop. 2015;41(6):1040-46. doi: 10.1111/cch.12274

15. Frederick A. Between stigma and mother-blame: blind mothers' experiences in USA hospital postnatal care. Sociol Health IIIness. 2015;37(8):1127-41. doi: 10.1111/1467-9566.12286

16. Conselho Nacional de Saúde (BR). Resolução 466 de 12 de dezembro de 2012. Dispõe sobre as diretrizes e normas regulamentadoras de pesquisas envolvendo seres humanos. Conselho Nacional de Saúde. Brasília. 2012.

17. Conselho Nacional de Saúde (BR). Resolução 510 de 07 de abril de 2016. Dispõe sobre as normas aplicáveis a pesquisas em Ciências Humanas e Sociais. Conselho Nacional de Saúde. Brasília. 2016.

18. Bertaux D. Narrativas de vida: a pesquisa e seus métodos. Natal, RN: EDUFRN, São Paulo: Paulus; 2010.

19. Reis AT, Araújo GF, Paschoal Jr A, Santos RS. A escuta atenta: reflexões para a enfermagem no uso do método história de vida. Rev Min Enferm. 2012[cited 2018 Dec 02];16(4):617-22. Available from: https://www.reme.org.br/artigo/detalhes/569

20. Associação Jequieense de Cegos (AJECE). Site oficial [Internet]. 2019 [cited 2018 Dec 02]. Available from: https://ajecejequie.wordpress. com/about/

21. Santos IMM, Santos RS. A etapa de análise no método história de vida - uma experiência de pesquisadores de enfermagem. Texto Contexto Enferm. 2008;17(4):714-9. doi: 10.1590/S0104-07072008000400012

22. Winnicott DW. Os bebês e suas mães. 4a Ed. São Paulo. Wmf Martins Fontes; 2013. 112p.

23. Mota MS, Gomes GC, Petuco VM, Heck RM, Barros EJL, Gomes VLO. Facilitadores do processo de transição para o autocuidado da pessoa com estoma: subsídios para Enfermagem. Esc Enferm USP. 2015;49(1):82-8. doi: 10.1590/S0080-623420150000100011

24. Caldas CP, Berterö C. Health Promotion and Life Course Dynamics: transitions of Brazilian Elderly. Health. 2014;6:616-24. doi: 10.4236/ health.2014.67080

25. Korukcu O, Deliktas A, Kukulu K. Transition to motherhood in women with an infant with special care needs. Int Nurs Rev. 2017;64(4):593601. doi: 10.1111/inr.12383

26. Lima CFM, Caldas CP, Santos I, Trotte LAC, Silva BMC. Therapeutic nursing care: transition in sexuality of the elderly caregiving spouse. Rev Bras Enferm. 2017;70(4):673-81. doi: 10.1590/0034-7167-2016-0256

27. Belo LCO, Oliveira Filho P. Maternidade marcada: o estigma de ser mãe com deficiência visual. Saúde Soc. 2018;27(3):957-67. doi 10.1590/ S0104-12902018147798

28. Medeiros TM, Costa KNFM, Costa TF, Martins KP, Dantas TRA. Acessibilidade de pessoas com deficiência visual nos serviços de saúde. Rev Enferm UERJ. 2017;25[e11424]:1-6. doi: 10.12957/reuerj.2017.11424 